\title{
Economics
}

\section{Reviewing the Issues and Challenges of Electronic Banking Regime in Iran}

\author{
Mahsa Alikhani ${ }^{1}$, Ali Zare $^{2}$ \\ ${ }^{1}$ Faculty of Management, Islamic Azad University, Science and Research Branch, Tehran, Iran \\ ${ }^{2}$ Faculty of Law and Political Science, Islamic Azad University, Science and Research Branch, Tehran, Iran
}

Email address:

yahoo2220@gmail.com (M. Alikhani), alizare@srbiau.ac.ir(A. Zare)

To cite this article:

Mahsa Alikhani, Ali Zare. Reviewing the Issues and Challenges of Electronic Banking Regime in Iran. Economics. Vol. 7, No. 1, 2018, pp. 1-9. doi: 10.11648/j.eco.20180701.11

Received: January 3, 2018; Accepted: January 22, 2018; Published: April 13, 2018

\begin{abstract}
Technological advances have transformed the face of the world. Over the past two decades, the banking industry has been investing heavily in using Information Technology (IT). In response to new laws, the growth of global networks and rising incomes, the banking industry employs new technologies called e banking to achieve and maintain strategic benefits. Electronic banking refers to financial activities that are carried out using electronic technology. Electronic banking gives banks the opportunity to respond to the different needs of customers in different locations simultaneously. In recent years, with the growing spread of information technology and the benefit of the Internet, banks and financial institutions are seeking to provide more different and diverse services for their customers. The emergence and development of e-banking is facing serious challenges, which responding to them is inevitable. The challenges that the e-banking system will face include financial, regulative and legal issues, organizational culture and process issues, infrastructures and systems. One of the challenges of developing electronic banking in Iran is the legal challenge. One of the most important legal challenges for the e-banking system seems to be whether the general rules of contracts provide sufficient guarantees for the validity and necessity of electronic contracts. The purpose of this paper is to examine the legal challenges for the advancement of the electronic banking system and provide solutions for solving them.
\end{abstract}

Keywords: Electronic Banking, Information Technology, Legal Challenges

\section{Introduction}

In order to provide a definition of e-banking law, it is necessary to briefly provide a definition of banking. Banking in the legal system of the Islamic Republic of Iran is defined in accordance with the international procedure by mediating the funds between suppliers and applicants for funds in the form of receiving deposits under any name and title and granting of loans and facilities. In other words, banking is depositing of the public on the one hand and the provision of loans, credits and facilities on the other. This definition is reflected both in the regulation of the non-monetary market regulation and in the regulations governing the authorized banking operation approved by the Money and Credit Council in 2012. Electronic banking is to provide customers with access to banking services, using secure intermediaries without physical presence. The most important goals of the e- banking system include [20]:

1. Providing banking services using platforms and electronic gadgets;

2. Providing ongoing banking services even during the holidays;

3. Removing time and place constraints of banking services;

4. Increasing the speed and quality of banking services and reducing the cost of exchanging money.

Electronic banking is divided into three levels of information, communication and transaction. Information level is the most basic level of electronic banking. The bank provides information about its services and banking operations through public or private networks. Communication is a level of electronic banking that allows transactions between the banking system and the customer. This level of risk in e-banking is more than the traditional one, and it requires proper controls for not having access to 
the Internet Bank and computer systems. Transaction level is the highest level of risk associated with its type of information and communication and is able to issue checks, transfer funds and open an account with a controlled security system. Electronic banking law is a part of the law of knowledge that regulates the relations between the parties in electronic banking and the Internet at all three levels [17]. Obviously, with the expansion and complexity of each of these levels, the electronic banking law issues are also wider and more complex, and the range of legal issues raised in relation to the third level is not comparable to those that are being addressed at the first and second levels [4].

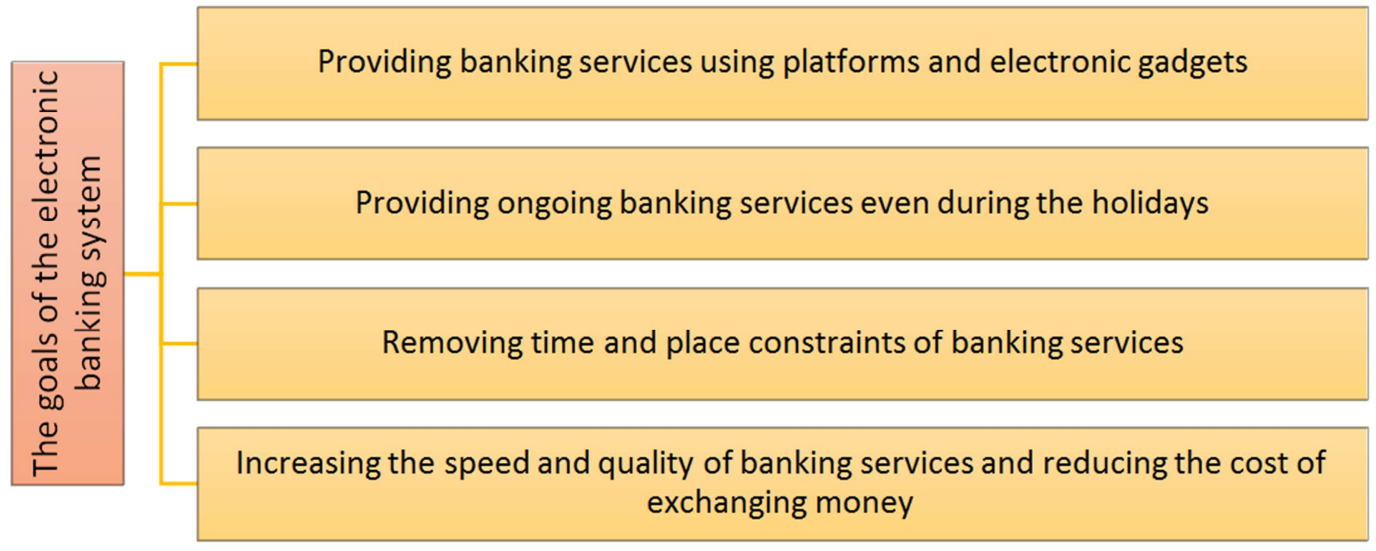

Figure 1. The Purposes of Electronic Banking System of Iran [18].

Electronic banking has different types that are referred to below:

1. Electronic banking

2. Mobile Based Banking

3. Telephone banking

4. Fax based banking

5. ATMs-based banking

6. Banking based on sales terminals

7. Banking based on self-contained electronic booths

Increasing the speed of data transmission and the formation of new and network-based economic platforms have aggravated economic transactions. Electronic banking system has played an important role in providing hardware and software infrastructures in this historic transition and transformation of Iranian business environment [2]. The continuous growth of network-based businesses and their cash flows, the growing popular acceptance of these types of businesses between customers all reflect the changing patterns of sales and the rapid pace of moving toward to faster and cheaper services [10]. Electronic banking creates many advantages for the business environment that the most important of them are:

At the enterprise level, the e banking allows banks to respond to the different needs of customers at different locations simultaneously. The purpose of the banking industry is making it easier and more convenient for customers to use these technologies. E Banking is the key for helping banks move from multiple locations to a global and lucrative market [1].

Table 1. Advantages of electronic banking [10].

\begin{tabular}{l}
\hline Advantages of Electronic Banking \\
\hline Increase speed and efficiency \\
Increase work accuracy \\
Avoiding fraud and abuse \\
Reduce costs \\
Increasing customer services \\
Saving time \\
Reduce traffic and pollution \\
Ease of access to banking services without time and space limitations \\
Increasing the speed of financial services and creating opportunities and \\
competitive advantages in providing services \\
\hline
\end{tabular}

\section{Electronic Banking System in Iran}

\subsection{Types of Electronic Banking}

Types of electronic banking include:

1. Non-branch banking;

2. Dual banking;

3. Virtual banking.

Table 2. Types of Electronic Banking and their Features [18].

\begin{tabular}{|c|c|c|}
\hline \multirow{5}{*}{$\begin{array}{l}\text { Types of Electronic } \\
\text { Banking }\end{array}$} & non-branch banking & $\begin{array}{l}\text { 1. The service is provided only through electronic channels without the need for attending in the branch } \\
\text { 2. Use of contact points such as post offices or some bank branches as a partner }\end{array}$ \\
\hline & \multirow{2}{*}{ dual banking } & 1. A combination of traditional and electronic banking \\
\hline & & 2. Providing services through customer referral to branches as well as through electronic channels \\
\hline & \multirow{2}{*}{ virtual banking } & 1. Providing services via the Internet and in cyberspace \\
\hline & & 2. The integration of customers and users and the simultaneous use of online banking services \\
\hline
\end{tabular}

Different types of electronic banking have different kinds of similarities and differences that can be distinguished in the following table: 
Table 3. Similarities and differences between various types of electronic banking [18].

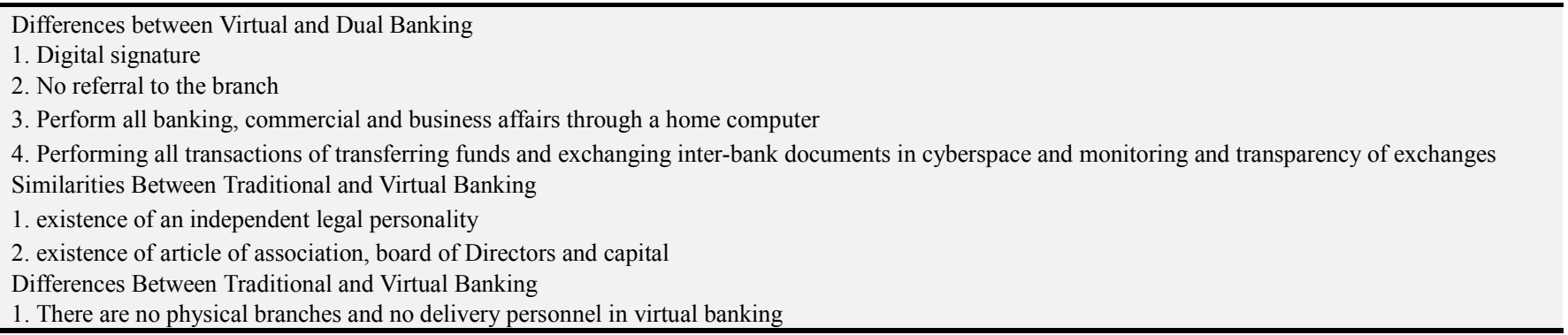

Nevertheless, electronic banking has achieved significant achievements in its not so long time and has developed over the course of its time at all levels of society and has become almost an integral part of everyday life [3]. Electronic banking also releases employees from repetitive, simple, and routine tasks and allows them to devote their time to revenue generation. From a financial perspective, electronic banking can significantly affect the discount rate of banking. In particular, electronic banking reduces operational and administrative costs, and thus has a significant cost advantage for the banking industry [16].

Table 4. The achievements of the electronic banking system [16].

\begin{tabular}{l}
\hline Electronic Banking Achievements \\
\hline Electronic interbank communications \\
Implementing Centralized Banking Systems \\
Reduce the costs of branches and headquarters of banks \\
Expansion of electronic payment equipment and tools \\
Reduce the cost of doing banking activities \\
Expanding the use of Mobile Bank, Internet Bank \\
Electronic interbank receive and payment systems \\
Rising security and reducing the incidence of human error in banking \\
activities \\
The growing use of electronic money instead of paper money
\end{tabular}

\subsection{Electronic Banking Levels}

Internet banking is usually explored at three levels [11]:

1. Informing level: At this level, the bank provides its potential customers with the opportunity to create a website for its services, which can be provided by it, as well as the costs and manner of providing those services through the database. This level is the most basic level in electronic banking. The bank provides information about its services and banking operations through public or private networks.
2. Communication level (access to information via the Internet): At this level, the customer can refer to the bank's website for information on the flow of accounts and operations of his account and provide the necessary information regarding the activities carried out on the account. Communication level is a level of electronic banking that allows transactions between the banking system and the customer. The risk of this level is more than the traditional one, and it requires proper controls for not having access to the Internet Bank and computer systems.

3. Performing banking operations via the Internet. At this level, the client can perform numerous operations, such as transferring funds between accounts, paying installments and debts, and so on, through internet intermediaries without having to go to the branch office. Transaction level is the highest level of risk associated with its type of information and communication and is able to issue checks, transfer funds and open an account with a controlled security system.

Electronic banking at two levels of communication and transaction is a structure that is based on an agreement and contract. In the legal analysis of the contractual relationship between people who are in some way related to e-banking, there is no way of resorting to general principles and rules governing contracts [16].

\subsection{Electronic Banking Challenges in Iran}

The electronic banking system as a new system is facing a number of challenges in different societies which include educational, systemic, legal, cultural, organizational, process and infrastructure challenges.

Table 5. Electronic Banking system challenges in Iran [18].

\begin{tabular}{|c|c|c|c|}
\hline $\begin{array}{l}\text { Electronic } \\
\text { Banking } \\
\text { system } \\
\text { challenges }\end{array}$ & $\begin{array}{l}\text { Systemic } \\
\text { challenges }\end{array}$ & Hardware & $\begin{array}{l}\text { Lack of a centralized banking system in all banks of the country } \\
\text { Lack of proper hardware with the size of banking operations } \\
\text { The initial cost of hardware systems } \\
\text { The lack of specific standards in software systems } \\
\text { The initial cost of software systems } \\
\text { Not paying attention to the potential of domestic software in the field of finance and banking } \\
\text { Incompatibility of domestic banking operations with international banking operations and as a result of } \\
\text { incompatibility with international software } \\
\text { Lack of proper and comprehensive culture among banking users in the field of virtual banking } \\
\text { The lack of trust among the various strata of the population towards virtual banking } \\
\text { Users think that virtual banking is impractical and not secure }\end{array}$ \\
\hline
\end{tabular}




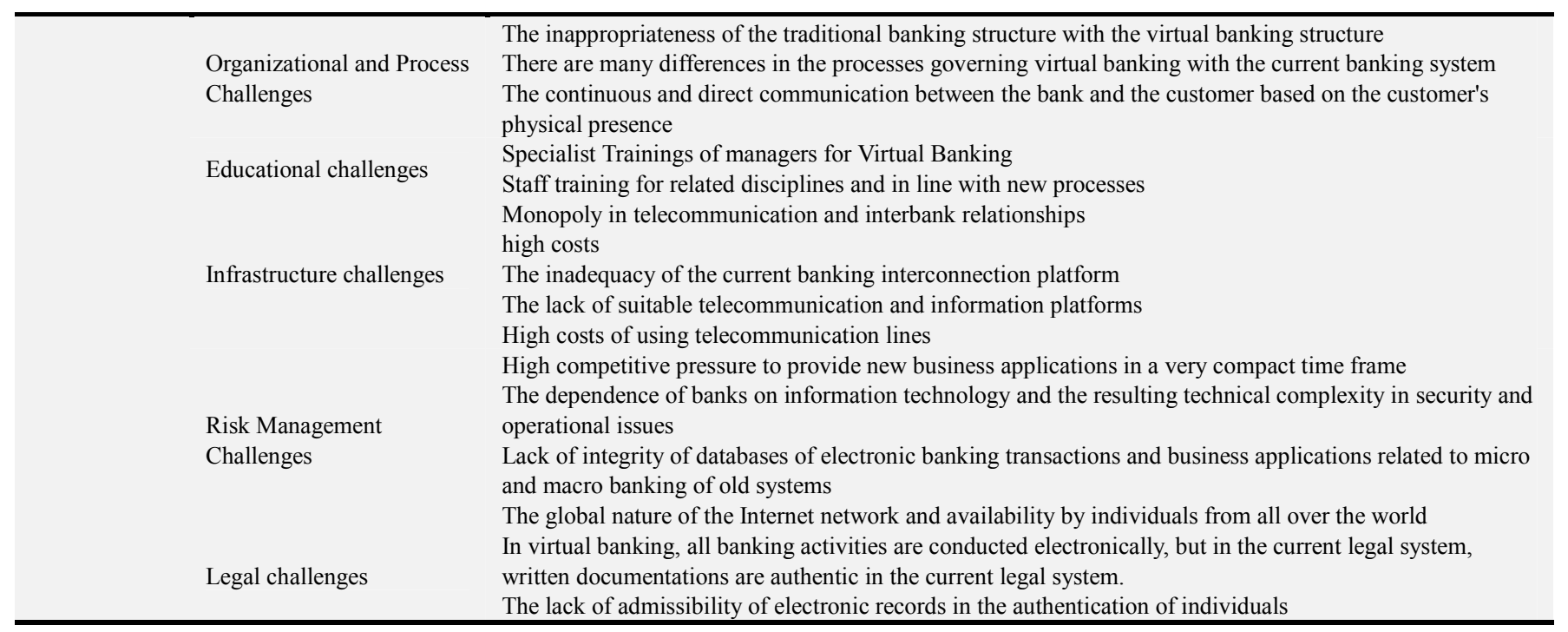

\section{Electronic Banking Laws}

Electronic banking law is a part of the law knowledge that regulates and controls the relations between the parties in electronic banking and the Internet at all three levels. Obviously, with the expansion and complexity of each of these levels, the issues of electronic banking law issues are also wider and more complex, and the range of legal issues raised in relation to the third level is not comparable to those that are being addressed at the first and second levels. [15].

\subsection{Electronic Banking Law Sources}

In relation to any discussion and legal issue, it is necessary to identify its sources. Electronic and Internet Banking Laws are the same laws and regulations as those related to relevant legal rules. In this regard, there are two specific rules that deal directly with electronic issues. The first is the ecommerce law. Although internet payments exempt from this rule, a significant range of issues that can be addressed between the bank and the client are excluded from the scope of this law. At the same time, it should be noted that this law, as the key law and the basis of electronic commerce law issues, cannot be ignored in electronic and Internet banking law, in spite of its numerous objections, because many basic issues and the key to e-commerce, including the definitions and fundamental concepts of this law. The second major law related to banking and e-commerce is the computer crime law. The law, enacted in 2009, provides the legal basis for combating cybercrime, and if a crime occurs in the context of the Internet and e-banking environment, the reference to this law will be inevitable [11].

In addition to the two laws, the regulations issued by the central bank on the various aspects of electronic banking and the Internet, as well as payment systems and regimes play an important role in electronic banking law. One of the functions of the Central Bank of the Islamic Republic of Iran is to regulate the rules governing payment systems in the country and monitor the correct implementation of those rules. In this regard, the central bank has issued several guidelines and regulations on the various aspects of payment systems and Internet banking from the regulations governing the establishment of virtual banks to the instructions of various payment systems. In these regulations, the rules of conduct, and sometimes the rights and obligations of the parties in relation to electronic and online banking and payment systems explain [2].

Another source that needs to consider in the e banking and Internet banking law is the agreements between the various actors in this regard. Contracts between banks and customers, banks with each other and banks with the central bank, all contribute to determining the salaries and duties of customers in the electronic banking system and the Internet and cannot be ignored in this regard. Of course, it should be noted that the contracts cannot be in violation of the laws and regulations of the central bank, and some of the terms and conditions set out in the contracts between the bank and the customers appear to be in some ways contrary to legal requirements.

Finally, the Consumer Protection Act should be mentioned as a new source for electronic and Internet banking. Persons who use e-banking and internet banking services are deemed to be consumers and therefore enjoy the protection rights set forth in the Consumer Protection Act. Therefore, it is imperative that these rights be examined in order to determine the extent of their application in the relationship between the bank and the customer in the field of electronic banking [11].

\subsection{The Status of Electronic Banking Laws in the Legal System}

One of the key issues with respect to e banking and Internet banking law is its status in knowledge of law. The purpose of this field is that e banking and internet banking law is a part of private law or public law. Private law is the branch of law, which deals with the relations of private individuals. However, public rights deal with government 
relations with people or institutions and organizations [5].

It is usual to regard electronic banking law as bank law and e-commerce law as a private law, and this is because both banks and their clients are private individuals and, as a matter of principle, none of them are governmental. Even government banks, as they do banking activities, act like private banks, not government agencies and institutions, and there is not any difference between public and private banks in this dimension. However, in accepting this theory, it should be careful in a number of ways:

First, because it is the government that sets and controls the rules governing banking activities, from depository to prudential supervision rules, and in pursuing these objectives, it is clear that the public interest of key concepts and principles in public rights are defined and its effects are discussed in public law.

Second, the government's involvement in banking activities, in the form of oversight and sometimes arbitrary interference often occurs, and the state's position in this regard cannot be ignored.

Third, the state sometimes as an actor also enters into banking activities, and it is impossible to understand and analyze some of the rules governing payment systems, regardless the status of the state.

Hence, while acknowledging the relationship between banking and private law, its broad and extensive connection with general legal issues cannot be ignored [13].

\subsection{Electronic Contract: Current Contract or Absentee Contract}

The legal nature of the relationship between the parties in the electronic contract is not out of the subject of the contract because the customer's agreement with the bank to receive the service or order to perform monetary and currency transactions is done in the form of the contract [5]. In the relationship between the two banks, any settlement or calculation is based on contracts that are structured in a special form and validated by competent persons with a position in each of the banks. The relationship between the banks providing Electronic Banking Services is also established in the form of a contract. In addition, any other interaction, such as that between banks and creditors, or a bank with payment intermediaries, is conceivable in the form of a contract. An electronic contract is not a specific type of contract, but the electronic description only indicates how it is formed, that is, the form of such contracts is electronically [16].

Contracts that are made through the Internet and in cyberspace are considered as absentee contracts. An absentee contract is a contract that its acceptance has been done without negotiation, from distance, by telegram, courier, telex, fax and so on. Because an electronic contract is a one that has not done directly between two sides of it by the ways such as negotiation and also there is a time interval and space distance between two parties in making it and accepting, is included in absentee contracts. Although Iran's civil law is silent about the absentee deal, it cannot be questioned about its authenticity because it accepts the commercial law and does not find a reason to overturn it in the law. Moreover, in Iran's law, the principle is based on the veracity of transactions and contracts concluded between individuals unless there is a reason for corruption, and since there is no reason to abstain from an absentee contract, then it is necessary to carry out the contract between the absentees. Therefore, electronic contracts, which are among the absentee contracts, are valid [21].

\section{Internet Banking and Contract Law}

According to Article 183 of the Civil Code, a contract means that one (or several) persons are obliged to act against one (or several) other persons and the agreed agreement is acceptable to them [9]. Accordingly, it can say that electronic contract is the agreement and cooperation of two or more wills in order to create legal effects by electronic means. The first set of issues raised in relation to e banking and internet banking law are issues related to contract law. In the context of contracts for Internet and e banking, this should be considered when is it the time to conclude online and electronic banking contracts? In response to this question, you can compare e banking and Internet banking contracts with a postal contract. When it is the time of the signing a postal agreement, there are several possible views:

1. The contract is concluded when the second side is written his acceptance

2. The contract is concluded when the second side is mailed his acceptance

3. The contract is concluded when the first side is received the acceptance

4. The contract is concluded when the first side after receiving the acceptance is informed of its content [11].

Among the four theories, most jurists have accepted the second theory (the theory of posting). Accordingly, it can be concluded that in the event that the contract of banking services is also electronically or online, the contract is deemed to be concluded when the customer sends his acceptance to the bank in an Internet manner [20].

Another issue is that how signing an internet banking contract could be possible. In this regard, attention should be paid to various types of signatures. A signature type referred to as a "click" is a condition in which a customer verifies the content of the contract by clicking on an option that states the terms of the contract have been accepted by him. In such a situation, clicking on the option will be deemed to accept the terms of the contract. The other mode is considered to be browse wrap. In this case, it is announced to the customer that the continued use of the bank's website means accepting the bank's contractual terms. In such a case, the client, using the base services, declares his consent to the contract terms [18]. Although such a signature is valid, however, it should be noted that if the bank changes the content of the Internet contract, given that the client does not re-examine all of the contract terms at each visit to the base and assumes that it does not change it the bank should make the changes in a 
way to inform the customer and obtain customer satisfaction. In other words, since it is assumed that such contracts will not be changed, the customer must be informed against this assumption. Another issue with regard to electronic banking contracts is whether these contracts are considered to be complementary contracts. In such a case, what is the impact of extensionality on these contracts? Another issue to be solved in this regard is how to resolve this disagreement if there is a conflict between the bank and the client in relation to how the parties fulfill their obligations in relation to electronic banking. The following is an attempt to briefly answer this question [20].

\subsection{The General Rules of Electronic Contracts}

The most important reason for being an electronic contract is its co-ordination with the use of electronic equipment. An electronic agreement is an agreement that is made with all the necessary conditions for the negotiation and agreement to be reached electronically and through the message data created with the computer or similar electronic equipment. Almost all lawyers believe that an electronic contract in terms of the essential terms of the transaction's health is no different from the ordinary contract and the existence of these conditions in the contract is necessary [22]. The formation of contracts does not usually require special formalities, and as soon as the will of the individuals to establish a legal nature is announced and agreed upon, a contract between them is formed. The method of declaring will is not important, but any means that implies the intention to create individuals can produce legal effects. Now, in electronic contracts, the will of people crosses through electronic devices and brings legal effects. Therefore, the purpose of the electronic contract is to have a specific (non-specific) agreement, which is concluded through electronic intermediaries. That is, the announcement of the will of the writer electronically in an intangible and virtual space [16].

The conclusion of a contract in cyberspace is generally similar to that in the real world, and there is no major difference between them. For the conclusion of a contract, such as electronic, etc., the existence of the essential conditions of the transaction's accuracy, as referred to in Article 190 of the Civil Code, is necessary. The reason for this is the adherence of electronic contracts to public rules [20].

There are several basic conditions for the correctness of each transaction; intention is the most important element of any legal action. According to the law, if there is no intention to do a contract, it is not valid and there will be no effect on it. Of course, the inner intention is not enough to create a bargain, but that internal will needs to be stated; that is, the parties of the transaction must express their intent and conscience in words, and in other words Transaction is not done [12].

The other condition of the transaction is that the parties must be qualified for the transaction, and the transaction with those who do not have qualification is invalid. For being qualified, they must be mature and wise. In every good deal, the subject of the transaction must be clear, so the transaction cannot be one of two or more specific objects, for example, if someone pledges to transfer or his own home or garden to another or pledges to transfer each of them that the other party wants, it is not a valid contract [13].

The last basic condition of transaction accuracy is the legitimacy of the transaction. The intention of the transaction is the issue and the incentive that is found before the transaction in each of the interlocutors and causes the transaction to be carried out. For example, someone who is indebted to sell his house to pay off his debt, to pay for the debt is the intention of the transaction. The intention is the fact that each interlocutor before the transaction imagines. The intention prompts the interlocutors to carry out the deal, in order to achieve their goals. Almost all lawyers believe that an electronic contract in terms of the essential terms of the transaction's accuracy doesn't have any differences with ordinary contract and the existence of these conditions in the contract is necessary [8].

\subsubsection{Intention of the Parties}

What drives the creation of a legal nature is the will of human beings. The will is the constructor of legal action because it is a legal act of credit and there is no legal nature without the interference of the will of the parties. Therefore, the first condition for the creation of contracts is the will of the parties [21]. That is why the article of the Civil Code stipulates: "A contract is to be made for the purpose of writing on the condition of being affordable to something which implies the intention". It is understood from the concept of the material, what leads to the realization of the contract is the existence of the intention, but since the will is an internal and psychological matter, and its realization is not inherently external to it, this will be expressed in a way to be effective in creating legal effects. In the light of what has said, there is no analytical difference between the requirement of ordinary and electronic acceptance. However, the point has to be considered is that the claim for electronic acceptance based on the references and the sending of signs that are not approvable will not be acceptable [7]. In electronic exchanges, as in the case of ordinary contracts, how to declare a claim and accept it is often determined by the parties' affairs or the circumstances. The need for acceptance of the contract can be stated, if the parties agree, by exchanging message data via e-mail, online gambling, and chat service. If the message data is used to form a contract, it cannot deny the validity or functionality of it [16].

The data transferred in electronic exchanges and the conclusion of a contract through electronic mail between the parties and as a means of announcing, the will of the parties to the contract should be explicit and clear in two aspects:

1. First, in terms of the general rules of the contract, that is, if the content of the claim or the acceptance is not specific, the contract condemned to fail, in such a way that it is impossible to understand the true intention of the interlocutors.

2. Second, the scientific and technical aspect; explaining 
that the message data exchanged should be readable to the other party. Therefore, if the data sends under an undocumented program and the other party does not understand the content of the message, even if the submitter expresses his true intention and is legible for himself, then it is not possible to make an electronic contract [20].

The bank and the client must first create an agreement to establish a legal relationship between themselves, then they express their inner self-determination through any action that they intend to do. Therefore, the bank and the client must establish a legal relationship between themselves in the first step, and then they will declare their intrinsic will through every action that they intend to do. If the bank and the customer intend to provide and use services such as issuing checks, transfer funds and opening an account electronically, this contract may define in the form of a rental contract The lease of contract services is the basis for the parties agreeing that one of them opts for another to receive a fee from another. These services do not have a specific scope and can include any legitimate service, including banking services [2]. In the implementation of an Internet banking contract with a service lease, it can be argued that the bank undertakes to provide all or some of the banking services through the Internet in return for receiving a commission from a customer. When the bank wants to provide services to the client in exchange for a price charge, it should establish a contract that defines the relationship between the bank and the client within the framework of the rental service. The bank expresses the need for a contract with the customer, and the customer has accepted it by signing the contract [15].

There are two significant drawbacks in the analysis of the contract for the leasing of banking services. First, many banks do not receive remuneration in exchange for ebanking services, which reduces the cost of the bank and the need for labor, and, by providing free services, encourages customers to use it; However, in the rental agreement, it is received in return for service fees. Secondly, in the rents of services, the type of work that a person undertakes must be clear. However, the range of bank services can change and can be reduced or increased or new services can provide [6].

\subsubsection{Qualification}

In accordance with article 210 of the civil Code, parties of a contract must be qualified. Lack of qualification for transaction may be general (such as a crazy or childless person) or a particular (such as a protector or a minor). For parties to be qualified, they must be mature and wise (article 211 of the Civil Code Act). The transaction with persons who are not adult or wise is in vain due to lack of qualification (article 212 of the Civil Code). In fact, the result of the lack of qualification is invalidity of the contract. In electronic contracts, in accordance with the general rules of contracts, the authenticity of the parties to the contract must establish in a relationship that is in some way associated with the Internet Banking authority. This issue is important because the parties in electronic contracts do not see each other. There is no major problem in electronic banking regarding to understanding the bank qualification, because in case of doubt the customer can use ways such as the registration number in a given country, the address and domain name, trademark of the bank. The inquiry should make through the Industrial Property Registration and Ownership Office and the Company Registration Office. Of course, in accordance with article 31 of the Commercial Code, the Bank may be required to design and introduce digital signatures through electronic certification services, thereby recognizing the identity of the bank [19].

Although identity differs from qualification, it is possible to confirm the qualification with proper exploring of interacting identities and examination of their conditions such as age, puberty, etc. In the case of the exploring the qualification of juridical and natural persons who enter into Internet bank in any way, providing their own personal information by completing the certain forms and confirming them by their electronic signature is a good way [9]. The major problem in this way is identity fraud or identity theft. In particular, in quick withdraws form the account that a person by a fake identity may enter into a bank account and withdraw from all the accounts or transfer money from ATMs. It seems that in order to overcome this problem and increase the security factor in electronic exchanges, modern methods should be used that minimize the possibility of identity theft and fraud [6].

In order to ensure the accuracy of the deal, the dealers must be qualified, that means they are mature, and wise. In some cases, customers may optionally give their credit card or their own password to another person to use their banking services. In this case, if the nature of the banking contract is to rent services, then it may be possible for the client to afford the right to benefit from the service for free or even in exchange for a fee. If a customer gives the right to benefit from the electronic services to another person in exchange for a fee, a renewal rental contract has been made. However, as one of the parties to the transaction is the bank, it is necessary to obtain the acceptance of the bank in order to conclude the second contract. Without the acceptance of the bank, the person who holds another card does not have the right to exploit the banking service. However, if the nature of the contract is authorized, the bank may only assume the client's legal representation in banking, and it is not satisfied that will do business with authorizing from someone other than the customer. In the authorizing contract, the bank must also deal directly with the client's affairs without any intermediary, and cannot ask another bank to take over the affairs [19].

\subsubsection{Certain Issues}

In accordance with article 214 of the Civil Code, the transaction shall be the property or practice that each of the partners enters into, or submits, a commitment. According to article 215 , the good or service of transaction must worth and secured a rational legitimate interest. If the bank and the 
client to create a contract for the provision of services or advocacy for the provision of and benefit from the modern banking services, the subject of the contract has economic value. However, it seems that in some cases, determining the deal is facing problems. For example, in some cases, the services that the bank pledges to provide to the client is not mentioned in the contract or explicitly stated. In addition, if the bank is committed to providing certain specified services to the customer, it is required to conclude a contract for the provision of new services not mentioned in the contract. Nevertheless, if it provides services in absolute terms, there is no need to conclude a new contract [21].

\subsection{Legitimacy of the Transaction}

Article 217 of the Civil Code states that the transaction does not need to be specified, but if specified, it should be legitimate and otherwise the transaction is void. According to the Civil Code of Iran, mentioning the order of the transaction is not necessary, but if it is mentioned it must be legitimate, otherwise the transaction is void. Therefore, the illegitimate order in a transaction is making it void if mentions in the contract. The transaction order is the same as an indirect and non-interactive motivation that is encouraged to do the transaction. For example, a person buys a land for establishing a cement factory. The main motive for the buyer is the construction of a cement factory that is admissible from the religious point of view. However, if the person's motivation is to buy land for constructing a wine factory is an illegitimate transaction [12].

It is not necessary to mention the order in a banking contract like other contracts, but if it is mentioned, its legitimacy must be verified. In order to deal with the bank's contract, in other words, the Bank's motivation to provide electronic banking services is to increase speed and efficiency, reduce costs and reduce the need for labor, which is not in a strictly religious situation [16].

\subsection{Prove the Lawsuit}

One of the key issues in electronic banking is that who is liable for the burden of proofing in the dispute between the bank and the client? While the traditional system puts the burden of claims the burden of proofing on the shoulders of the claimant, the reality of electronic banking is such that makes it difficult to use this traditional system. From a legal point of view, transferring funds in electronic banking differs by transferring funds in traditional banking. In traditional banking, funds transfer is made, for example, through a check that has its own identity and retains that identity. The purpose of identity is that the check has the name and signature of a person. If that person has the right to sign the check, his signature is correct, and this accuracy can be assessed and recognized at any time, and if he does not have the right to sign and forges it, this forgery can be detected at any time. Is. However, in electronic banking, entering an account number through an ATM or PC at home does not have these features, and authenticity or fake cannot be recognized. That is, it cannot be determined that the password has been entered by the account holder or authorized person from the account holder or someone else who has stolen the password. In other words, the password loses its identity when it arrives, which makes it difficult to assess its accuracy and credibility. Therefore, in electronic banking, the proof of the claim is mainly the same computer data that the bank has and the customer does not have access to. This, in turn, leads to inequality between the bank and the client, which is the basis and the basic principle of the procedure and the legal system governing the proof of the dispute. Now that this basis is not in the cases between the bank and the client, the principle is also required to be amended. It can be seen that the legislator, if he wants to apply the traditional system of evidence in electronic banking, ignores the facts that clearly indicate the inequality of the parties to the dispute and ignores the principle of equality of the parties to the lawsuit. The trials of courts in the leading countries of electronic banking show that the burden of proofing the litigation in electronic litigation cases has been largely in the hands of the bank, and even in cases where the bank is a claimant and based on the traditional rules of litigation, There was no need to give a reason, but the bank still had to provide the reasons [11].

\section{Conclusion}

The electronic contract is not a specific type of contract, but the electronic description only indicates how it is formed, that is, the form of these contracts are electronically. Almost all lawyers believe that an electronic contract in terms of the essential principles of the transaction's accuracy is no different from the ordinary contract and the existence of these conditions in the contract is necessary. In accordance with the general rules of the contracts, the bank and the client must make an agreement for establishing a legal relationship between themselves, and then, by whatever actions that show their intention express their own inner will. Since the intention of the bank and the client is providing and using of electronic banking services, this contract can define in the form of a leasing contract. In electronic contracts, the qualification of the partners, the subject of the contract and its legitimacy must be identified. In relation to some issues of e-banking law, there are various gaps in Iran. Existing laws and regulations do not explicitly state electronic payment orders, and even the e-commerce law is silent about them. The rules of consumer protection in relation to electronic banking are incomplete and, unfortunately, there is no clear and coherent judicial procedure in this regard; and also in relation to some services that may be offered in the near future, such as banking, using cloud computing, there are no specific legal rules and there may be several legal issues in this regard. Therefore, the legislator needs to take the necessary measures, taking into account the needs and necessities of the present, before serious problems and large legal cases with wide implications for individuals and the judiciary take place. 


\section{References}

[1] Aladwani, A. M. (2013). Online banking: A field study of drivers, development challenges, and expectations. [Electronic version]. International Journal of Information Management, $21(3), 213-225$.

[2] Allameh, Seyyed Mohsen and Zare, Seyed Mohsen. (2007), Investigating the Factors Affecting the Reception of Electronic Banking, Tehran: Second World Conference on Electronic Banking.

[3] Agarwal, R., \& Prasad, J. (1999). Are individual differences germane to the acceptance of new information technologies? [Electronic version]. Decision Sciences, 30 (2), 361-394.

[4] Bandura, A. (2002). Growing primacy of human agency in adaptation and change in the electronic era [Electronic version]. European Psychologist, 7 (1), 2-16.

[5] Davis, F. D. (2012). Perceived usefulness, perceived ease of use, and user acceptance of information technology. [Electronic version]. MIS Quarterly, 13 (3), 319-341.

[6] Elsan, Mostafa (2005). Formation of Electronic Contracts, Commercial Journal, No. 36.

[7] Elsan, Mostafa (2006), Requirements and Acceptance of Electronic Transactions, Quarterly Journal of Legal Research, No. 43.

[8] Elsan, Mostafa (2009), Legal aspects of Electronic Banking, Quarterly Journal of Legal Research, Monetary and Financial Research Institute.

[9] Emami, Seyed Hassan (1986). Civil Rights, Tehran: Islamiyah Publications.

[10] Flavian, C., Torres, E., \& Guinaliu, M. (2004). Corporate image measurement: A further problem for the tangibilization of Internet banking services. [Electronic version]. The International Journal of Bank Marketing, 22 (4/5), 366-381.

[11] Ghanbari, Hamid. (2016). Study of the necessary platforms for implementation of the e-banking system and its challenges, the center for the development of banking and e banking.

[12] Jafari Langroudi, Mohammad Jafar (1999). Expanded in Terminology, Tehran: Ganj Danesh Publications.

[13] Jahangir, Mansour (1998), Civil Code, Tehran: Visiting publication.

[14] Joseph, M., \& Stone, G. (2015). An empirical evaluation of US bank customer perceptions of the impact of technology on service delivery in the banking sector. [Electronic Version]. International Journal of Retail and Distribution Management, $31(4 / 5), 190-203,190-204$.

[15] Maleki, Mehdi and Akbari, Peyman. (2011). Investigating the Role of Electronic Banking in Iran, Bank Quarterly and Economics, No. 112.

[16] Molakarimi, angel. (2014). Legal Review of Electronic Banking Based on General Contracts, Monetary and Financial Research.

[17] Ndubisi, N. O. (2016). Integrating the moderation effect of entrepreneurial qualities into the technology acceptance model and treatment of potential confounding factors. [Electronic version]. Journal of Information and Science Technology, 2 (1) $28-48$

[18] Rasulov, Javad (2012). E Banking, Achievements, Challenges and Future Horizons, Quarterly Journal of Economics, Year ninth, No. 134.

[19] Shadkam, Hamed. (2009). Legal and Financial Challenges in Electronic Banking in Iran, Master's thesis, Iranian Banking Institute.

[20] Seyyed Abadi, Zahra. (2015). Legal Review of the Challenges of E-Commerce, Tehran, Allameh Tabatabaei University.

[21] Seyyed Jawadin, Reza and Saghtchi, Maryam. (2006), Electronic Banking and its Development, Tadbir Monthly, No. 170 .

[22] Wesali Naseh, Morteza. (2006). Electronic contract and its credit bases. Magazine Kahn, No. 66. 